\title{
THE COST OF BEING NONWHITE AND THE ADDED COST OF BEING FEMALE IN THE SOUTH AND SOUTHWEST
}

\author{
Patricia E. Gaynor and Garey C. Durden*
}

\begin{abstract}
In this paper we use CPS data from 1990 to investigate earnings differences between white males and others in the South and Southwest. Particular emphasis is placed on measuring the added cost of being female-that is, the amount by which earnings differentials for white, black, and Mexican-American females exceed those of black males. We find that the earnings of black males, after adjustment for labor market differences, still lag behind those of white males. We find a substantial extra cost of "femaleness" in that unexplained earnings differentials for females are greater than those for black males. For white females the unexplained differential is $\mathbf{4 4 . 9}$ percent, $\mathbf{8 9 . 3}$ percent, and 51.2 percent greater for white, black, and Mexican-American females than for black males.
\end{abstract}

\section{INTRODUCTION}

Although the 1972 Equal Employment Opportunity Act prohibits discriminatory hiring and promotion, several studies (Verdugo 1992; Kwabena and Fichtenbaum 1994; Cotton 1988a, 1988b, 1985; Carlson and Swartz 1988; Blau and Beller 1988; Filer 1985; Reimers 1983; Gwartney and Long 1978; and Smith and Welch 1977), and others have suggested that there is still a considerable "cost" to being female and/or nonwhite, as opposed to being white and male. Depending upon the nature of adjustments for market-related differentials such as experience, training and education, the earnings of women and minorities are still estimated to be somewhere between one-half and three-fourths of those of white males. The exception to this general condition is for males of Asian (particularly Japanese and Eastem Indian) origin.

One purpose of this paper is to determine whether there are remaining unexplained earnings differentials between white males and black and MexicanAmerican reference groups living in the South and West. The reason for limiting the analysis regionally is that the South and Southwest are the areas where relatively large numbers of reference group members reside. ${ }^{1}$ A second, less examined and therefore more interesting, purpose is to determine whether there are additional costs to "femaleness." ${ }^{2}$ To determine this, we measure the amount (if any) by which earnings differentials (costs) for white, black and Mexican-

*Professors of Economics, Appalachian State University, Boone, NC. 
American females living in the South and Southwest exceed earnings differentials for similarly located black males.

A few studies (Corcoran and Duncan 1979; Cotton 1988a) have attempted to measure the added cost of being female, finding it to be substantial. The contribution of this study is that the data we use are much more recent (at least 10 years later in time) and that we use yearly earnings, whereas earlier studies used hourly earnings. Finally, neither earlier study considered the relative position of Mexican-American females in the earnings hierarchy.

The reason for attempting to separate race and gender effects is that if antidiscrimination policies are to be effective, then the sources and consequences of discrimination must be as clearly illuminated as is possible. If gender-based earnings inequality is more severe and, perhaps, fundamentally different from that associated with race, then it is possible that a certain degree of policy tailoring may be necessary. For example, women have long been more visible in lowerpaying occupations and have had more trouble in being promoted to levels of higher responsibility and pay within occupations and industries. ${ }^{3}$ While specific policy measures are beyond the scope of this analysis, the results produced here may provide a basis for policy-related discussions.

In order to analyze earnings differences, a simple, human-capital-based model and data from the March, 1990 CPS summary file are combined to provide earnings estimates for white males and each of the reference groups. ${ }^{4}$ The sample consists of employed workers who are 16 years of age or older. Total estimated earnings differences are decomposed (using the methodology developed in the economics literature by Oaxaca (1973) and Blinder (1973) (OB) and extended by Cotton (1988) and Neumark, (1988) (CN)) into skill (endowment) effects and unexplained residual effects which are due to a combination of discrimination and choice-based factors. ${ }^{5}$

Section 2 is a discussion of $\mathrm{OB}$ and $\mathrm{CN}$ methodologies, the model and proxy variables are discussed in section 3, and empirical results are presented and analyzed in section 4. As earlier noted, because of the inclusion of MexicanAmerican females in the regressions, and because of the relatively larger population of blacks in the south, we follow Verdugo (1992) in restricting the data to those individuals living in the South and West. A brief summary in section 5 completes the paper.

\section{METHODOLOGIES FOR MEASURING DISCRIMINATION}

In individual 1973 papers, Ronald Oaxaca and Alan Blinder took significant steps in developing a methodology which attempts to isolate a discrimination- 
based earnings residual. The decomposition methodology developed by $\mathrm{OB}$ is based on the behavioral model:

$$
\ln E_{i}=a+\Sigma B_{j} X_{j}+e_{i}
$$

where $\ln E_{j}$ is the log of earnings for each group, $a$ is the constant term, $X$ is a vector of the $\mathrm{j}$ independent variables which are theoretically linked to individual earnings, $B$ is a vector of $\mathbf{j}$ corresponding parameters and $e$ is the error term. From equation 1 , individual regressions are run using the method of ordinary least squares (OLS) and $\ln E_{\mathrm{i}}$ estimated for white males and for each of the comparison groups according to;

$$
\ln \bar{E}_{i}=a+\Sigma \mathrm{B}_{\mathrm{j}} \bar{x}_{j}
$$

where $a$ and $b$ are parameter estimates derived from the use of a sample of data and proxy variables to represent the theoretically established linkages noted in equation 1 . The bar superscripts denote sample means.

The OB decomposition methodology is operationalized for computation of endowment and residual effects according to;

$$
\ln \bar{E}_{w m}-\ln \bar{E}_{r g}=\sum\left(\bar{x}_{w m}-\bar{x}_{r g}\right) B_{w m}+\sum\left(B_{w m}-B_{r g}\right) \bar{x}_{r g}
$$

where the wm subscript refers to the white male benchmark and the rg subscript refers to a given reference group, either black males or white, black or MexicanAmerican females. The first term on the right side is the average difference in income due to differences in endowments between white males and the respective reference group. Differences in endowments include such factors as education, experience, job or occupation, etc. The second term on the right is the residual effect, which is assumed to be the result of possible discrimination and choicebased factors.

The OB adjustment attempts to provide a glimpse of how the earnings of a currently disfavored group would compare with those of a currently favored group if all earnings inequality between individuals were adjusted for human capital and other socioeconomic differences, with discriminatory practices absent, and with members of reference groups generally making similar work-related choices. Earnings differential estimates so adjusted would be: $\operatorname{lnEd} \mathrm{bm}_{\mathrm{bm}}$ $=\ln E D_{w f}=\operatorname{lnED_{bf}}=\ln E D_{m f}=0$.

The Cotton/Neumark reformulation suggests that the $\mathbf{O B}$ method is seriously flawed because it does not allow for the fact that removal of discrimination would 
lower the earnings of favored groups and raise earnings for those who have previously been disfavored. ${ }^{6}$ For example, if discrimination in hiring were completely ended, the supply of workers into relatively more preferred and higher paying jobs would increase, and the marginal product of workers currently employed in these markets would decline. In less-preferred and lower-paying occupations, the supply would relatively decrease, raising marginal product and earnings. It is also probable that the demand for disfavored workers would increase, while the demand for favored group members would decrease, reinforcing the earnings changes.

The $\mathrm{CN}$ reformulations assume that the discrimination-free earnings of individuals will be somewhere between those of the white male and reference groups. ${ }^{7}$ The problem, then, is to separate existing unexplained residuals into the earnings premium (advantage effect) enjoyed by white males and the earnings cost (disadvantage effect) imposed on others by current labor market conditions, which may be, at least in part, discrimination based. ${ }^{8}$ This is accomplished by first computing a vector of discrimination-free pseudo coefficients, $\mathrm{B}^{*}$, and using them to adjust the results from the regression equations according to:

$$
\left.\ln \bar{E}_{w m}-\ln \bar{E}_{r g}=\Sigma \bar{x}_{w m}-\bar{x}_{r g}\right) B *+\sum_{w m}^{-}\left(B_{r g}-B *\right)+\Sigma_{r g}^{-}\left(B *-B_{r g}\right) .9
$$

The first composite term on the right side is that portion of the earnings differential which is due to differences in attributes between white male and reference group members, which Cotton calls the skill differential. The second composite term is that amount of the differential which is possibly due to the advantage gained by white males because of discriminatory practices in labor markets. The third term measures the related earnings disadvantage suffered by members of the reference group.

\section{THE MODEL AND PROXY VARIABLES}

In order to obtain the parameter estimates necessary for operationalizing the Oaxaca/Blinder and Cotton/Neumark procedures (from equation 1) the following human-capital based equation was estimated using individual data points. ${ }^{10}$

$$
\ln \bar{E}_{i}=a+B_{1}\left(\overline{x_{1}}\right)+B_{2}\left(\overline{x_{2}}\right)+B_{3}\left(\overline{x_{3}}\right)+B_{4}\left(\overline{x_{4}}\right)+B_{5}\left(\overline{x_{5}}\right)+B_{6}\left(\overline{x_{6}}\right)+e
$$


where X1-X6 are vectors of independent variable proxies for each of the i groups (white male, black male, white female, black female, Mexican American female) and where:

Vector X1, Human Capital: HghGrade, the highest grade of school completed; ${ }^{11}$ Experience, the number of years on the job experience as measured by age-educ-6; ExpSq, the square of the experience variable.

Vector X2, Family Related: Dummy variables with value 1, zero otherwise for marital status (Married, Divorced), head of household (HHead) and a continuous variable for number of children in the family who are 15 years old or younger (Under 15).

Vector X3, Spacial Related: CenCity and SMSA, dummies with value=1 if the individual lives in a central city and/or SMSA, zero otherwise.

Vector X4, Industry Type: Dummy variables with value=1 for wholesale trade (WhTrade), retail trade (ReTrade), (Const), finance, insurance and real estate (FIRE), durable goods manufacturing (DuManuf), nondurable goods manufacturing (NdManuf), transportation and communications (TransCom) and professional services (ProfSer), with Other Services as the reference (value=0) category.

Vector X5, Government Employment: Dummy variables with value of 1 for Federal, State and Local government employment.

Vector X6, Other Influences: A continuous variable for number of employers during the past year (NEmplrs) and dummy variables if self-employed (SelfEmp) or if employed Fulltime. The variable Lambda is included to adjust for sample selection bias (Heckman, 1980). ${ }^{12}$

\section{EMPIRICAL RESULTS}

The estimated earnings for white males and the reference groups and the mean values of variables used in the regressions are presented in Table 1. As summarized in the first two rows of the table, Mexican Females have the lowest relative earnings, about 40 percent, on average, as much as white males. For the other groups, black females, white females, and black males, respectively, earn 48 percent, 52 percent, and 67 percent as much as white males.

The most important differences for between-group means are associated with education and experience levels and with the incidence of full-time employment. Mexican-American females have considerably less education than others, more than two years fewer than black males, the next lowest group; black males have a year less education than white males and females; and black females have more than a half year less than white males and females. White males are substantially 
TABLE 1

Estimated Earnings and Mean Values of Variables Used in Regressions

\begin{tabular}{|c|c|c|c|c|c|}
\hline & $\begin{array}{l}\text { White } \\
\text { Males }\end{array}$ & $\begin{array}{l}\text { Black } \\
\text { Males }\end{array}$ & $\begin{array}{c}\text { Black } \\
\text { Females } \\
\end{array}$ & $\begin{array}{c}\text { White } \\
\text { Females }\end{array}$ & $\begin{array}{c}\text { Mex-Am } \\
\text { Females }\end{array}$ \\
\hline Ln(Salary) & 9.681 & 9.284 & 8.948 & 9.037 & 8.724 \\
\hline Dollars & 16011 & 10764 & 7692 & 8409 & 6149 \\
\hline HghGrade & 13.374 & 12.265 & 12.703 & 13.329 & 10.915 \\
\hline Experience & 19.268 & 19.133 & 18.412 & 18.748 & 17.826 \\
\hline ExpSq & 554.584 & 554.570 & 516.314 & 537.656 & 481.185 \\
\hline HHead & .751 & .627 & .442 & .279 & .243 \\
\hline Married & .637 & .516 & .383 & .583 & .535 \\
\hline Divorced & .095 & .125 & .209 & .151 & .143 \\
\hline Under15 & .686 & .867 & 1.027 & .658 & 1.333 \\
\hline SMSA & .697 & .749 & .751 & .695 & .873 \\
\hline CenCity & .206 & .386 & .383 & .204 & .365 \\
\hline TransCom & .144 & .152 & .057 & .068 & .065 \\
\hline WhTrade & .116 & .118 & .331 & .306 & .227 \\
\hline ReTrade & .154 & .125 & .165 & .212 & .205 \\
\hline FIRE & .046 & .031 & .057 & .087 & .062 \\
\hline ProfSer & .116 & .118 & .331 & .306 & .227 \\
\hline DuManuf & .121 & .116 & .052 & .053 & .079 \\
\hline NdManuf & .074 & .105 & .103 & .066 & .121 \\
\hline Const & .127 & .099 & .006 & .021 & .007 \\
\hline Federal & .037 & .052 & .077 & .031 & .019 \\
\hline State & .041 & .037 & .051 & .049 & .035 \\
\hline Local & .058 & .091 & .118 & .101 & .091 \\
\hline NEmplrs & 1.259 & 1.196 & 1.168 & 1.239 & 1.194 \\
\hline SelfEmp & .071 & .018 & .007 & .032 & .012 \\
\hline Fulltime & .765 & .701 & .669 & .626 & .601 \\
\hline Lambda & .805 & .227 & .020 & -.507 & .375 \\
\hline $\mathbf{N}$ & 15782 & 2028 & 2360 & 14162 & 1760 \\
\hline
\end{tabular}

more likely to be employed full time than all groups, ranging from 6.4 percentage points greater than black males to 16.4 percentage points greater than MexicanAmerican females. White and black males have as much as a year more experience than others.

These differences almost surely contribute more to earnings differentials than just the straightforward measures associated with computation of endowment effects. Fewer years of education probably limit entry into higher paying jobs and detrimentally affect the probability of promotion to greater levels of responsibility and the associated higher earnings. Fewer years of experience and a lower in- 
cidence of full time employment may have similar negative effects on both earnings and job characteristics. ${ }^{13}$

Table 2 shows the estimations for white males and for each of the comparison groups. ${ }^{14}$ The results, although mixed, suggest that (1) for MexicanAmerican females, the rate of return to education is dramatically smaller (less than half) than that of the other groups: (2) the benefits of being married are substantially larger for males than for females and the number of children under 15 significantly reduces earnings for all but white males; (3) residing in an SMSA increases the incomes of all but Mexican-American females; (4) black males tend to have higher percentages of employment in the blue-collar trades, which add more to earnings, while females tend to have relatively higher employment percentages in the white-collar, less lucrative areas; and (5) white and black females gain about 30 percent in earnings when employed in the Federal government sector.

Table 3 provides estimates of logged values of earnings differences, between white males and each of the reference groups, using the Cotton-Neumark extension of the Oaxaca-Blinder methodology. So that the reader can more easily judge the nature of differences, we also report the dollar value counterparts, which are derived by taking the appropriate antilogs. Table 3 clearly suggests that, extending the results of the previous studies cited in section 1, all other groups continue to incur a relative earnings "cost" as compared to white males. The total cost of not being white and male appears to be greatest for Mexican-American females- .957 in log terms, and $\$ 9,862$ in 1990 dollars. The smallest cost is for black males.397 ; $\$ 5,246$ : for white and black females, the corresponding numbers are .644 , $\$ 7,602$, and $.733 ; \$ 8,318$.

Skill related (endowment effect) earnings differences account for from 45-63 percent of the total earnings difference between white males and the four reference groups. For black males, the unexplained residual effect is $.184, \$ 2,413$, and 46 percent of the total differential, while the corresponding numbers for white, black and Mexican-American Females are; $.299, \$ 3,497,46$ percent; .404, $\$ 4,568$, 55 percent; and $.355, \$ 3,649,37$ percent.

Following Cotton $(1885,1988 \mathrm{a}, 1988 \mathrm{~b})$, the residual effect is further partitioned into (1) a portion which is due to the 'advantage' or overpayment to white males caused by favorable demand and supply conditions in labor markets; and (2) a portion which is due to the 'disadvantage' or underpayment to other groups. ${ }^{15}$ The white males' advantage effect is .198 , which may be interpreted as indicating that favorable labor market conditions cause the log of earnings for white males to be .198 (19.8 percent) greater than they would be in a discrimination-free world where all groups make similar choices. When the earnings of black males and white, black and Mexican-American females are compared to white males (rows $1,2,3,4$ columns 4,5 of the table), in all but one case, over half 
TABLE 2

Earnings Estimating Equations

(T-values in Parenthesis: * Indicates an Insignificant Result)

\begin{tabular}{|c|c|c|c|c|c|c|c|c|c|c|}
\hline \multirow[b]{2}{*}{ HghGrade } & \multicolumn{2}{|c|}{$\begin{array}{l}\text { White } \\
\text { Males }\end{array}$} & \multicolumn{2}{|c|}{$\begin{array}{l}\text { Black } \\
\text { Males } \\
\end{array}$} & \multicolumn{2}{|c|}{$\begin{array}{c}\text { Black } \\
\text { Females }\end{array}$} & \multicolumn{2}{|c|}{$\begin{array}{c}\text { White } \\
\text { Females }\end{array}$} & \multicolumn{2}{|c|}{$\begin{array}{l}\text { Mex-Am } \\
\text { Females }\end{array}$} \\
\hline & .1067 & (26.95) & .0979 & $(10.53)$ & 11157 & (11.18) & .1066 & (26.87) & .0472 & $(4.91)$ \\
\hline Experience & .0582 & $(27.31)$ & .0459 & $(8.92)$ & .0433 & $(7.90)$ & .0446 & (19.28) & .0498 & (6.58) \\
\hline ExpSq & -.001 & $(23.60)$ & -.0007 & (7.64) & -.0006 & (6.12) & -.0008 & (18.1) & -.0008 & (5.1) \\
\hline HHead & .3216 & (16.98) & .2750 & (5.49) & .2601 & (5.86) & .1885 & (7.89) & .1248 & (1.91) \\
\hline Married & .2915 & (12.91) & .3030 & (5.19) & .1730 & (3.07) & .1872 & (7.26) & .042 & $(0.62)^{*}$ \\
\hline Divorced & .1277 & $(4.41)$ & .0074 & $(0.10)^{*}$ & .0433 & $(0.73)^{*}$ & .1136 & (3.64) & -.096 & $(1.1)^{*}$ \\
\hline Under 15 & -.0106 & $(1.4)^{*}$ & -.0394 & (2.16) & -.0513 & (2.88) & -.1188 & (12.8) & -.046 & (2.28) \\
\hline SMSA & .2328 & (14.73) & .2932 & (5.45) & .3402 & $(6.04)$ & .2327 & (12.19) & .1274 & (1.68) \\
\hline CenCity & .0338 & $(1.89)$ & -.007 & $(0.13)^{*}$ & .1184 & (2.26) & .0547 & (2.50) & .0946 & $(1.85)$ \\
\hline TransCom & .2685 & (9.95) & .1850 & (2.63) & .4705 & (4.70) & . 4749 & (10.79) & .6740 & (4.94) \\
\hline WhTrade & -.1187 & (3.15) & -.105 & $(0.91)^{*}$ & -.4125 & (1.86) & -.098 & $(1.52)^{*}$ & -.12 & $(0.66)^{*}$ \\
\hline ReTrade & -.0598 & (2.55) & -.3502 & (5.04) & -.1402 & (2.09) & .0615 & (2.31) & .1961 & (2.67) \\
\hline FIRE & . 1474 & (4.15) & -.022 & $(0.19)^{*}$ & .3109 & (3.28) & .4269 & (12.51) & .5263 & $(4.80)$ \\
\hline ProfSer & -.1149 & (4.46) & -.2372 & (3.38) & .078 & $(1.36)^{*}$ & .2438 & (9.66) & .2689 & (3.58) \\
\hline DuManuf & .2612 & (10.26) & .2106 & (2.91) & .3674 & (3.76) & .5541 & (13.50) & .6131 & (6.19) \\
\hline NdManuf & .2403 & (8.05) & .1342 & (1.80) & .3447 & (4.34) & .3606 & (9.57) & .4716 & (5.55) \\
\hline Const & .1829 & (7.41) & -.027 & $(0.36)^{*}$ & -.142 & $(0.57)^{*}$ & .4101 & $(6.81)$ & -.05 & $(0.17)^{*}$ \\
\hline Federal & .1122 & (3.01) & .105 & $(1.14)^{*}$ & .3113 & (3.97) & .3580 & (7.25) & .140 & $(0.81)^{*}$ \\
\hline State & -.056 & (1.56)* & .2184 & (2.02) & .071 & $(0.76)^{*}$ & .2405 & (3.16) & .208 & $(1.56)^{*}$ \\
\hline Local & -.032 & (1.06)* & .093 & $(1.27)^{*}$ & 1397 & (2.05) & .0829 & (2.76) & .1638 & (1.79) \\
\hline NEmplrs & -.149 & (11.9)* & -1362 & (3.37) & .056 & $(1.27)^{*}$ & -.0348 & (2.19) & .005 & $(0.09)^{*}$ \\
\hline SelfEmp & -.2209 & (8.06) & -.3951 & (2.69) & -.4891 & (2.10) & -.2101 & $(4.45)$ & -.686 & (3.15) \\
\hline FullTime & .9434 & $(51.40)$ & .9849 & (20.62) & 1.055 & (22.23) & 1.154 & (62.7) & 1.158 & (22.6) \\
\hline Lambda & -.019 & $(0.70)^{*}$ & .022 & $(0.64)^{*}$ & .0815 & (2.38) & .003 & $(0.17)^{*}$ & .1491 & (3.75) \\
\hline Constant & 6.5037 & & 6.549 & & 5.659 & & 6.029 & & 6.512 & \\
\hline R-Square & .512 & & .497 & & .461 & & .444 & & .426 & \\
\hline
\end{tabular}

of the unexplained residual involves the white male advantage. This translates as 108 percent of the residual, $\$ 2,606$ for black males; 66 percent, $\$ 2,308$ for white females; and 56 percent, $\$ 2,043$ for Mexican-American females. For black females, 51 percent of the residual effect $(\$ 2,329)$ can be attributed to labor market disadvantage effects; while the numbers for white females and MexicanAmerican females are 34 percent, $\$ 1,189$ and 44 percent, $\$ 1,605$. The disadvantage effect for black males is actually negative (but very small, -8 percent and -\$193), suggesting the possibility that, when adjusted for skill differences, and black male/white male differences, and with discrimination absent, the prevailing wage structure would be the same for black males.

Table 4 compares female earnings differentials with those of black males in order to determine whether there is an extra cost to "femaleness." In every case, the Corcoran and Duncan (1979) and Cotton (1988) hourly earnings results are supported: When white male/black male yearly earnings differentials are sub- 
TABLE 3

The Cost of Being Minority and (or) Female, as Compared to Being White and Male

\begin{tabular}{|c|c|c|c|c|c|}
\hline & $\begin{array}{l}\text { Total } \\
\text { Cost } \\
\end{array}$ & $\begin{array}{c}\text { Skill Related } \\
\text { Cost }\end{array}$ & $\begin{array}{l}\text { Unexplained } \\
\text { Residual Cost }\end{array}$ & $\begin{array}{c}\text { White Males } \\
\text { Advantage }\end{array}$ & $\begin{array}{l}\text { Other Group } \\
\text { Diendventre }\end{array}$ \\
\hline $\begin{array}{l}\text { White Males } \\
\text { Compared to: }\end{array}$ & & & & & \\
\hline Black Males & $\begin{array}{c}.397 \\
(\$ 5246)\end{array}$ & $\begin{array}{c}.213(54 \%) \\
(\$ 2832)\end{array}$ & $\begin{array}{c}.184(46 \%) \\
(\$ 2413)\end{array}$ & $\begin{array}{c}.198(108 \%) \\
(\$ 2606)\end{array}$ & $\begin{array}{c}-.014(-8 \%) \\
(-\$ 193)\end{array}$ \\
\hline White Females & $\begin{array}{c}.644 \\
(\$ 7602)\end{array}$ & $\begin{array}{c}.345(54 \%) \\
(\$ 4105)\end{array}$ & $\begin{array}{c}.299(46 \%) \\
(\$ 3497)\end{array}$ & $\begin{array}{c}.198(66 \%) \\
(\$ 2308)\end{array}$ & $\begin{array}{c}.101 \quad(34 \%) \\
(\$ 1189)\end{array}$ \\
\hline $\begin{array}{l}\text { Black } \\
\text { Females }\end{array}$ & $\begin{array}{c}.733 \\
(\$ 8318)\end{array}$ & $\begin{array}{c}.33(45 \%) \\
(\$ 3750)\end{array}$ & $\begin{array}{c}.404(55 \%) \\
(\$ 4568)\end{array}$ & $\begin{array}{c}.198 \quad(49 \%) \\
(\$ 2238)\end{array}$ & $\begin{array}{c}.206 \quad(51 \%) \\
(\$ 2329)\end{array}$ \\
\hline $\begin{array}{l}\text { Mexican- } \\
\text { American } \\
\text { Females }\end{array}$ & $\begin{array}{c}.957 \\
(\$ 9862)\end{array}$ & $\begin{array}{c}.600(63 \%) \\
(\$ 6213)\end{array}$ & $\begin{array}{c}.355(37 \%) \\
(\$ 3649)\end{array}$ & $\begin{array}{c}.198(56 \%) \\
(\$ 2043)\end{array}$ & $\begin{array}{c}.156(44 \%) \\
(\$ 1605)\end{array}$ \\
\hline
\end{tabular}

tracted from white male/female differentials, there is an additional cost to being female.

The total earnings differential for black males is $\$ 5,246$, while for white, black and Mexican/American females, the differentials are $\$ 7,602, \$ 8,318$ and $\$ 9,862$, respectively. The total cost to "femaleness" for white women is $\$ 2,356$, 44.9 percent more than the cost of being black male. For black females and Mexican/American females, the corresponding numbers are, $\$ 3,072$ (58.6 percent); and $\$ 4,616$ ( 87.9 percent), respectively.

Skill-related characteristics account for $\mathbf{5 4 . 8}$ percent of the total differential for black males and 51.0 percent, 35 percent, and 70 percent for the respective female groups. (See percentage figures to the right of the dollar amounts.) The percentages below the dollar figures show the amounts by which female differentials in the skill category exceed those for black males. (See percentages below dollar values, 44.8 percent; 32.4 percent; 119.3 percent). Notable in these figures is that the equalizing of market-related characteristics (becoming more like white males in endowments) would pay much greater dollar amount benefits to female groups relative to black males. In percentage terms, equalization would have about the same effect for black males and white females, would have somewhat less effect for black females, and would have substantially more effect for Mexican/American females.

The unexplained portion of the total differential for black males is $\$ 2,413$ (45.2 percent). For white females, the unexplained portion is $\$ 3,497,49$ percent of the total differential. The cost to white females, in yearly earnings, which might 
be associated with labor market discrimination, is $\$ 1,084$ greater, 44.9 percent more, than for black males. For black females, the unexplained portion is $\$ 4,568$ (65 percent), thus exceeding the black male residual by $\$ 2,155$, more than 89 percent. Mexican/American females show a residual of $\$ 3,649$ (30 percent), which is $\$ 1,236$ and 51.2 percent greater than the black males' residual. From these results, it is apparent that there are substantially greater costs to "femaleness," which might be discrimination-based. The relative cost for black females is greatest, and the cost for white and Mexican/American are roughly equal.

\section{SUMMARY AND CONCLUSIONS}

The purposes of this paper have been to update the analysis of yearly earnings differentials between white males and others and to analyze the extra cost of femaleness, measured as the difference between earnings differentials for black males and those for white, black and Mexican-American females living in the South and Southwest. To do this, we have employed an extension of the OaxacaBlinder methodology which was developed by Jeremiah Cotton (1985). The Cotton extension creates a discrimination-free wage structure which incorporates the appropriately weighted wage structures of all relevant populations. This procedure

\section{TABLE 4}

The Added Cost of Being Female: The Dollar and Percentage Amounts by Which Female Earnings Differentials Exceed Those for Black Males

\begin{tabular}{|c|c|c|c|c|c|}
\hline \multirow[b]{2}{*}{ Black Males } & \multirow{2}{*}{$\begin{array}{c}\begin{array}{c}\text { Earnings } \\
\text { Differential }\end{array} \\
\$ 5246\end{array}$} & \multicolumn{2}{|c|}{$\begin{array}{c}\text { Skill-Related } \\
\text { Portion }\end{array}$} & \multicolumn{2}{|c|}{ Unexplained } \\
\hline & & $\$ 2832$ & & $\$ 2413$ & \\
\hline White Females & $\$ 7602$ & $\$ 4105$ & $(51 \%)$ & $\$ 3497$ & $(49 \%)$ \\
\hline Femaleness Cost (\$) & $\$ 2356$ & $\$ 1273$ & & $\$ 1084$ & \\
\hline Femaleness Cost (\%) & $(44.9 \%)$ & $(44.8 \%)$ & & $(44.9 \%)$ & \\
\hline Black Females & $\$ 8318$ & $\$ 3750$ & $(35 \%)$ & $\$ 4568$ & $(65 \%)$ \\
\hline Femaleness Cost (\$) & $\$ 3072$ & $\$ 918$ & & $\$ 2155$ & \\
\hline Femaleness Cost (\%) & $(58.6 \%)$ & $(32.4 \%)$ & & $(89.3 \%)$ & \\
\hline Mexican-American Females & $\$ 9862$ & $\$ 6213$ & $(70 \%)$ & $\$ 3649$ & $(30 \%)$ \\
\hline Femaleness Cost (\$) & $\$ 4616$ & $\$ 3381$ & & $\$ 1236$ & \\
\hline Femaleness Cost (\%) & $(87.9 \%)$ & $(119.3 \%)$ & & $(51.2 \%)$ & \\
\hline
\end{tabular}


accounts for the fact that white male wages would fall, and those for other groups would rise as labor market supply and demand changes occur.

We find that earnings for white males still lead those of other groups. Much of this difference is due to skill or endowment differences, but a substantial unexplained residual remains. When black male earnings differentials are compared with those for female groups, we find that there are clear and substantial extra costs to being female, which are demonstrated in lower yearly earnings.

The Cotton method shows that the disadvantage effect for females, caused by the relatively preferential (detrimental) treatment accorded white males (reference groups), is much greater than for black males. For black males the disadvantage effect is actually negative, although very small, suggesting that if black males had the same characteristics as white males and white male labor market advantages were to disappear, the yearly earnings of black males would change little. The conclusion is that in discrimination-free labor markets, the prevailing wage structure would resemble that of black males. The disadvantage effect is $\$ 1,189$, $\$ 2,329$, and \$1,605 greater for white, black and Mexican/American females as compared to black males.

Extra costs to "femaleness" are also evident in the examination of residual effects. Unexplained residuals exceed those for black males by $\$ 1,084$ (44.9 percent), $\$ 2,155$ (89.3 percent), and $\$ 1,236$ (51.2 percent) for white, black and Mexican American females, respectively, indicating that "femaleness" may result in greater discrimination levels.

Mounting objections to affirmative action programs will almost certainly result in significant changes. Whether these changes are appropriate, and to what degree, is for others to decide. However, we believe the kind of information and analysis provided here, showing that there is still a considerable premium to "whiteness" and an extra cost to "femaleness," can and should be an important element of the debate.

\section{ENDNOTES}

1. Analysis of overall earnings differentials has been treated in another study (Durden and Gaynor 1997) which is forthcoming in the American Journal of Economics and Sociology. Taylor and Gwartney-Gibbs (1985) argue in this journal that analysis of regional earnings differences, particularly in the South, is important because of existing variation in regional segmentation.

2. As Amott and Matthai (1991) have shown, a completely pure gender effect will be difficult to isolate, since race-ethnicity and gender may have over- 
lapping effects and because females of different races have differing socioeconomic and historical experiences.

3. Hodson and England (1982) not only find this to be the case, but suggest that human capital theory fails to explain the existing condition. See endnote 5 for additional comments.

4. While most previous studies have used hourly, we use yearly earnings. This provides an assessment of earnings differentials from all sources and may provide superior results in non-wage earnings that are influenced by discrimination. The CPS does not directly provide hourly earnings.

5. As several recent studies have pointed out, there are serious shortcomings involving interpretation of results that are, associated with existing decomposition methodologies. Most criticism centers on the fact that prior discrimination in access to education, entry into higher-paying jobs, etc., may have contributed to lower levels of pay and job status for women and minorities. Other, more subtle forms of discrimination may also have provided contributing factors. Thus, to say that such skill-related factors as education, level of experience, occupation, and the like, are strictly matters of choice is questionable and may cause the effects of discrimination to be understated. Important work in this area has been done by Darity (1980; 1982), Bloom and Killingsworth (1982) and Killingsworth (1993).

6. It has long been recognized that results from the $O B$ method differ if, instead of assuming that the male wage structure will prevail in the absence of discrimination, one assumes that the female structure will prevail. The $\mathbf{C N}$ reformulation allows a proportional contribution of all groups to the discrimination-free wage structure.

7. We specifically use the Cotton method (as explained). The Neumark method is slightly different in that the discrimination-free coefficient estimates are obtained from pooled regressions. The methodologies produce very similar results.

8. As a reviewer notes, the $\mathbf{C N}$ method is limited, since it cannot account for the fact that white male/other group unemployment rates will also change with the elimination of discrimination. However, we think the extensions of $O B$ improve the decomposition procedures because nondiscriminatory earnings will be somewhere between those of white males and others.

9. In this formulation, $B^{*}$ is modeled by Cotton (1988a) as a simple linear function of the $\mathrm{B}_{\mathrm{wm}}$ and the $\mathrm{B}_{\mathrm{rg}}$ 's and the nondiscriminatory wage structure is assumed closer to the current white male wage than to the other race/gender groups. Thus B* is the weighted average of the $B_{w m}$ and $B_{r g}$ 's. The weights (f) are the proportions of white, black and Mexican-American males and females employed in the civilian labor force. In other words 


$$
B^{*}=f_{w m} B_{w m}+f_{w f} B_{w f}+f_{b m} B_{b m}+f_{b f} B_{b f}+f_{m m} B_{m m}+f_{m f} B_{m f}
$$

10. The data base is the March, 1990 CPS file from the U.S. Census Bureau.

11. As a reviewer points out, no measures of school quality, observable skills and IQ are available in the CPS. When Armed Forces Qualifying test scores were used in earnings equations (O'Neill 1990) the assumed discriminatory differentials disappeared, suggesting possibly biased results when CPS data are used. Maxwell (1995) has shown that school quality may vary by race and a reviewer notes that the variance may well be greater in the South. We agree however, AFQT tests may themselves be culturally biased, a condition which may mask discrimination. If lower-quality schooling causes us to underestimate potential discrimination, this is the direction in which we wish to err. We note that the present study has these shortcomings and that the use of potential rather than actual experience may also introduce biases. The CPS data do not allow us to deal fully with these issues, but criticisms and shortcomings may point toward future research efforts.

12. An important assumption in regression is that the expected value of the random disturbance term in the sample is zero. However, some people, for various reasons, choose not to be in the labor force. Since these people are selectively excluded from the sample, there is a high probability that, for the observed sample, the expected value of the disturbance terms is non-zero. Heckman (1979) has shown that this problem can be viewed as an omitted variable bias and has thus developed a procedure for accounting for the specification error. Briefly, the procedure involves using data from those not in the labor force as well as those in the labor force to estimate a probit equation that will relate the probability of an individual's being in the labor force to a number of determinants. One can then use these probit parameter estimates to compute the inverse Mills ratio (lambda). Lambda can then be added to the labor force equation as an additional variable. If the estimated coefficient on lambda produces a nonsignificant t-ratio, the null hypothesis of no self-selection bias cannot be rejected. In other words

$$
Y_{i j}=f\left(X_{i j} B_{j} / F\left(X_{i j} B_{j}\right)\right)
$$

where $\mathrm{f}($.$) is the standard normal density function and F($.$) is the standard normal$ distribution function.

13. As suggested earlier, treatment of these endowment differentials as wholly the result of choice, as the existing decomposition methodologies require, almost surely results in a downward bias in the assessment of how discrimination affects earnings inequality. However, disentangling choice effects from those which are discrimination based will be an extremely difficult task which cannot 
be properly accomplished here. Our purpose in frequently focusing on this particular defect in existing methodologies is to prompt others to begin thinking more carefully and perhaps join us in future efforts to resolve the problem.

14. Due to the limitations of space, only an abbreviated discussion of the individual variable coefficients is offered here. A more thorough discussion is available upon request.

15. The discrepancy in the values for the endowment term in the $\mathbf{O B}$ procedure and the skill term in the Cotton procedure is due to the fact that the endowment term is computed using $B_{w m}$, while the skill term is computed with $B^{*}$.

\section{REFERENCES}

Amott, Teresa L., and Julie A. Mattaei. Race, Gender and Work, A Multicultural History of Women in the United States. South End Press, Boston, 1991.

Blau, F.D., and A.H. Beller. "Trends in Earnings Differentials by Gender." Review of Economics and Statistics 41 (1988): 513-29.

Blinder, A.S. "Wage Discrimination: Reduced Form and Structural Estimates." Journal of Human Resources 8 (1973): 436-55.

Bloom, D.E., and M.R. Killingsworth. "Pay Discrimination Research and Litigation: The Use of Regression." Industrial Relations 21 (1982): 318-39.

Carlson, L.A., and C. Scwartz. "The Earnings of Women and Ethnic Minorities, 1959-1979." Industrial and Labor Relations 41 (1988): 530-52.

Corcoran, M., and G.J. Duncan. "Work History, Labor Force Attachment, and Earnings Differences between the Races and Sexes." Journal of Human Resources 14 (1979): 3-20.

Cotton, J. "Discrimination and Favoritism in the U.S. Labor Market." American Journal of Economics and Sociology 47 (1988a): 15-38.

Cotton, J. "On the Decomposition of Wage Differentials." The Review of Economics and Statistics 70 (1988b): 236-43.

Cotton, J. "More on the "Cost" of Being a Black or Mexican American Male Worker." Social Science Quarterly 66 (1985): 867-85.

Darity, W.A. "The Human Capital Approach to Black-White Earnings Inequality: Some Unsettled Questions." Journal of Human Resources 17 (1982): 72-94.

Darity, W.A. "Illusions of Black Economic Progress." Review of Black Political Economy 11 (1980): 153-68.

Filer, R.K. "Male-Female Wage Differences: The Importance of Compensating Differentials." Industrial and Labor Relations Review 38 (1985): 426-37. 
Gaynor, P.E. and G.C. Durden. "Measurement of the Pure Gender Effect on Yearly Earnings," 1997 forthcoming in the American Journal of Economics and Sociology.

Gwartney, J.D., and J.E. Long. "The Relative Earnings of Blacks and Other Minorities." Industrial and Labor Relations Review 31 (1978): 336-46.

Heckman, J.J. "Sample Selection Bias as a Specification Error." Econometrica 47 (1980): 153-62.

Hodson, Randy, and England, Paula. "Industrial Structure and Sex Differences in Eamings," Industrial Relations 25 (1986): 16-32

Killingsworth, M.R. "Analyzing Employment Discrimination: From the Seminar Room to the Courtroom." American Economic Review Papers and Proceedings 83 (1993): 67-72.

Kwabena, G.B. and R. Fichtenbaum. "Regional Differences in Labor Market Discrimination." Review of Regional Studies 24 (1994): 13-36

Maxwell, Nan L. "The Effect on Black-White Wage Differences of Differences in the Quantity and Quality of Education," Industrial and Labor Relations Review 47 (1994): 249-64.

Neumark, D. "Employers' Discriminatory Behavior and the Estimation of Wage Discrimination." The Journal of Human Resources (1988): 279-95.

Oaxaca, R. "Male-Female Differentials in Urban Labor Markets." International Economic Review 14 (1973): 693-709.

O'Neil, Jane. The Role of Human Capital Differences Between Black and White Men," Journal of Economic Perspectives 4 (1990): 25-45.

Ragan, J.F. Jr., and C. Tremblay. "Testing for Employee Discrimination by Race and Sex." The Journal of Human Resources 23 (1988): 121-37.

Reimers, C.W. "Labor Market Discrimination Against Hispanic and Black Men." Review of Economics and Statistics 65 (1983): 570-79.

Taylor, Patricia A., and Gwartney-Gibbs, Patricia A. "Economic Segmentation, Inequality, and the North-South Earnings Gap," Review of Regional Studies 15 (1985): 43-53.

U.S. Department of Commerce, Bureau of the Census. Current Population Survey: Annual Demographic File, 1990. [Computer file\}. 2nd release. Washington, DC: U.S. Dept of Commerce, Bureau of the Census, 1991.

Verdugo, R.R. "Earnings Differentials Between Black, Mexican American and Non-Hispanic Male Workers: On the Cost of Being a Minority Worker, 1972-1987." Social Science Quarterly 73 (1992): 661-673. 